\title{
POTENSI NOVEL CINTAKU DI LEMBATA KARYA SARI NARULITA SEBAGAI MEDIA PROMOSI PARIWISATA LEMBATA - NTT
}

\author{
Rimalinda Lukitasari \\ Politeknik Internasional Bali \\ Email: rimatanzil@gmail.com \\ Elsita Lisnawati Guntar \\ Politeknik Internasional Bali \\ Email: elsita.guntar@gmail.com \\ Ni Ketut Veri Kusumaningrum \\ Politeknik Internasional Bali \\ Email: very.ningrum@yahoo.co.id
}

\begin{abstract}
The designing of promotional media is an important thing in supporting the development of a tourism destination. With the tight competition among the destinations, the tourist choices are swinging choices. These days, the storytelling method is a method that highly buzzed in the marketing because it is considered effective to influence the future consumen emotionally. The novel of Cintaku di Lembata is a travellougue novel which tells about a tour to Lembata Island. Seing to its many predecors that has successfully raise the popularity of the destination that being used as the setting in the novel, then the potential of this novel to become a promostional media for Lembata - NTT is also worth to be researched. The purpose of this research is to know the potential of the novel of Cintaku di Lembata as a promotional media and the strategy that can be applied to maximize its utilization. The researched was conducted qualitatively with the data collection method of observation, interview, and focus group discussion (FGD). The theory that was applied was the theory of tourism promotion and the data analysis was done by using the SWOT method. The result shows that the novel of Cintaku di Lembata is very potential to become a tourism promotional media for Lembata because the content is informative and persuasive. However, there are some adjustments needed to maximize the utilization of the novel Cintaku di Lembata to promote Lembata - NTT. Those adjustments include, among others, in the matter of transforming the form into a film form and to choose the focus of attraction to be shown.
\end{abstract}

Keywords: Promotion, Destination, Storytelling, Cintaku di Lembata, NTT, SWOT

JUMPA Volume 7, Nomor 2, Januari 2021 


\section{Pendahuluan}

Pariwisata dapat berkembang dan maju jika didukung dengan berbagai kegiatan promosi. Dalam dunia pariwisata, promosi menjadi sangat penting untuk menarik perhatian wisatawan baik di kanca nasional maupun di kanca internasional. Bentuk pengembangan promosi pariwisata tidak saja dilakukan oleh pemerintah dan industri, tetapi juga membutuhkan campur tangan masyarakat sebagai pelaku pariwisata.

Kegiatan promosi idealnya dilakukan secara berkesinambungan melalui beberapa media yang dianggap efektif dalam menjangkau pasar, baik cetak maupun elektronik, dan pemilihannya sangat tergantung pada target pasar yang hendak dituju. Karya-karya naratif yang mampu membangun cerita sehingga pembaca dapat terpengaruh secara emosional dapat dianggap sebagai media yang potensial. Seperti sudah banyak diketahui, para praktisi pemasaran dewasa ini banyak mendengungkan pentingnya storytelling dalam berbagai kegiatan promosi. Salah satu media naratif yang tentu saja tidak dapat disepelekan adalah novel. Karena kekuatan novel dalam mempenetrasikan suatu emosi ke benak pembaca cukup kuat. Namun, seiring dengan menurunnya minat baca di Indonesia, seperti yang terlihat pada indeks Alibaca Nasional yang masih tergolong redah (Puslitjakdikbud, 2019), pemasaran novel juga menghadapi permasalahannya sendiri.

Signifikansi karya narasi dalam mempengaruhi minat wisatawan untuk berkunjung ke suatu destinasi salah satunya disampaikan oleh Rahmadiani (2014). Pada penelitiannya terhadap siswa/siswi SMA Negeri 9 Bandar Lampung, tampak bahwa film berjudul $5 \mathrm{~cm}$ secara kuantitatif sangat mempengaruhi keputusan para remaja untuk mengunjungi Taman Nasional Bromo Tengger Semeru. Bujukan untuk mengunjungi destinasi ini hadir bukan hanya dari penampilan gambar-gambar pemandangan yang indah di destinasi, namun juga merupakan hasil dari bujukan 
emosinal dan moral yang hadir dari jalan cerita atau narasi yang dihadirkan. Seperti yang dipaparkan oleh Lukitasari (2017), bahwa narasi dalam film Eat Pray Love, yang juga berasal dari bentuk novel, mampu memberikan dorongan emosional dan moral bagi para penonton untuk mengikuti jejak tokoh utama dalam melakukan perjalanan ke Ubud. Hal ini menunjukkan potensi besar yang dimiliki novel untuk dijadikan media promosi pariwisata. Perubahan bentuk cerita yang diangkat menjadi film memang menduplikasi dampaknya, namun materi utamanya tetap adalah hasil karya sastra novel itu sendiri.

Contoh lain kuatnya pengaruh novel dalam mempengaruhi pariwisata dapat dilihat pada kasus Laskar Pelangi yang sudah sukses terlebih dahulu dalam bentuk novel sebelum diangkat menjadi film. Andriansyah, Tati Rajati, dan Fatia Fatimah (2012) menunjukkan bahwa mendunianya novel dan film Laskar Pelangi mengajak semua pihak khususnya masyarakat setempat untuk lebih berperan aktif mengedepankan faktor aman dan kenyamanan bagi wisatawan, yang tentu saja hal menjadi pemicu pengembangan pariwisata yang dapat meningkatkan perekonomian masyarakat sekitar. Hal ini menunjukkan bahwa promosi pariwisata sebagai dampak dari suksesnya novel juga mampu mengubah sikap masyarakat untuk membangun pariwisata di daerahnya.

Melalui karangan sastra (novel), pembaca yang mempunyai kecintaan akan perjalanan wisata tidak hanya terbantu dalam hal informasi mengenai gambaran geografis, pemerataan proyek pembangunan, destinasi wisata, kekayaan tradisi dan budaya masyarakat setempat, namun lebih lagi, karya sastra memiliki potensi untuk memberikan latar belakang emosional terhadap destinasi yang berangkutan. Novel Cintaku di Lembata (2016) karangan Sari Narulita merupakan suatu novel yang menarik untuk dikaji potensinya dalam mempromosikan pariwisata Pulau Lembata - 
NTT. Dalam novel tersebut, Sari Narulita menuturkan perjalanannya di Lembata, salah satu pulau di NTT yang belum dikenal banyak orang, namun memiliki kekayaan alam, budaya, tradisi yang indah dan unik. Seperti novel Eat Pray Love (2006) yang memberikan panduan perjalanan secara artistik, novel Cintaku di Lembata juga memadukan sastra dan pariwisata menjadi sebuah hal yang baru dan bersinergi. Narasi yang tertuang dalam bentuk jurnalisme sastra tersebut tidak hanya tidak semata-mata sebagai karangan fiktif belaka, namun dapat juga dipandang sebagai upaya promosi pariwisata untuk daerah Lembata- NTT, dan upaya ini layak dikaji potensinya untuk benar-benar dikembangkan lebih lanjut sebagai suatu bentuk promosi pariwisata.

\section{Metode dan Teori}

Novel Cintaku di Lembata diteliti dengan menggunakan metode kulitatifdeskriptif. Adapun metode analisis yang dipilih ialah dengan menggunakan analisis SWOT. Metode ini dirasa sesuai dengan tujuan penelitian yaitu untuk mengetahui potensi novel Cintaku di Lembata sebagai media promosi. Tahapan analisis akan dimulai dengan menganalisis faktor-faktor internal kekuatan (Strenght) dan kelemahan (Weakness), serta faktor eksternal peluang (Opportunity) dan ancaman (Threath). Faktor internal yang dimaksud di sini adalah kekuatan (S) dan kelemahan (W) dari sisi novel itu sendiri baik dari segi isi maupun dari segi penulisnya. Adapun faktor eksternal meliputi hal-hal yang berkaitan dengan potensi $(\mathrm{O})$ dan tantangan $(\mathrm{T})$ yang asalnya dari luar novel, seperti respon pembaca, potensi untuk difilmkan, perkembangan tren pasar, tanggapan stakeholder pariwisata di Lembata, dukungan pemerintah, kemajuan teknologi, kondisi sosial-ekonomi nasional dan global akibat pandemi. Perumusan faktor-faktor internal dan eksternal didapatkan dari hasil wawancara dan Focus Group Discussion (FGD) dengan narasumber dari kalangan 
akademisi, pakar pemasaran pariwisata, industri perjalanan wisata, pelaku industri perfilman, sastrawan, dan pembaca novel Cintaku di Lembata.

Teori yang digunakan dalam analisis adalah teori promosi pariwisata sebagai suatu bagian dari strategi untuk menarik wisatawan datang berkunjung ke destinasi wisata. Mempromosikan pariwisata tentu saja juga berarti mengkomunikasikan kualitas destinasi yang di antaranya, menurut Suwantoro (2004:7 0), terdapat tiga unsur pokok, yaitu mengenai daya tarik wisata atau bisa juga disebut atraksi, sarana, dan prasarana wisata. Perihal mengkomunikasikan kualitas destinasi ini, menurut Yoeti (2013:186-187), bukan hanya difokuskan pada bentuk informatif mengenai elemen-elemen pada destinasi namun lebih lagi juga harus mengandung unsur-unsur persuasif. Unsur bujukan harus tampil walaupun terselubung. Hal ini tentu saja karena pada akhirnya yang ingin dicapai dari adanya suatu kegiatan promosi bukan hanya untuk menciptakan efek kognitif, namun juga afektif, hingga akhirnya diharapkan berdampak konatif (Wibowo dan Priansa, 2017:170-171).

Dalam hal merancang isi pesan, Kotler dan Armstrong (2012: 415-417) menjelaskan bahwa ada tiga daya tarik yang dapat dieksplorasi, yaitu daya tarik rasional, emosional, dan/atau moral. Daya tarik rasional menampilkan manfaatmanfaat yang akan didapatkan jika menggunakan produk. Daya tarik emosional menyasar pada emosi positif maupun negatif yang dapat mendorong kepada tindakan pembelian. Daya tarik moral memanfaatkan rasa "baik", "benar", "layak untuk dilakukan" dari audiens yang pada akhirnya dapat mendorong pada tindakan pembelian. Daya tarik moral biasanya ditampilkan dalam bentuk dorongan untuk melakukan aksi sosial yang berdampak bagi kebaikan khalayak banyak. Dalam hal struktur pesan yang perlu dipertimbangkan adalah apakah suatu pesan promosi menampilkan kesimpulan atau membiarkan audiens menarik kesimpulan sendiri, 
lalu apakah argumen terkuat ditampilkan di awal atau di akhir pesan, dan terakhir mengenai apakah pesan hanya mengandung sisi positif produk atau juga menampilkan sisi negatifnya.

\section{Lembata - NTT}

Lembata merupakan sebuah kabupaten di Propinsi Nusa Tenggara Timur (NTT), Indonesia. Kabupaten ini berbentuk pulau dengan luas 1.266,40 kilometer persegi. Seperti kondisi iklim kawasan NTT pada umumnya, Lembata memiliki musim kemarau yang cukup panjang dengan musim hujan pendek antara tiga sampai empat bulan saja. Padang rumput merupakan suasana yang umum ditemui di Lembata, namun dapat juga ditemui belukar di beberapa bagian serta hutan heterogen yang memiliki pohon Kayu Putih Pahlawan. Ibukota kabupaten yang memiliki sembilan kecamatan ini ada di Lewoleba. Ragam daya tarik wisata yang diandalkan Lembata adalah kombinasi bentang alam antara gunung dan pantai yang masih asli dan indah, atraksi penangkapan ikan paus, masyarakat dengan kehidupan dan kesenian tradisional, serta rumah-rumah adatnya (Dinas Komunikasi dan Informasi Kabupaten Lembata, 2019)

\section{Novel Cintaku di Lembata}

Novel Cintaku di Lembata (2016), mengisahkan tentang perjalanan Kayla, penulis perempuan dari Jakarta yang pada masa mudanya adalah seorang artis peran, ke Lembata dalam rangka memenuhi ajakan sahabatnya Eleonora untuk mengikuti rombongan wisata Kementerian Pariwisata di tahun 2014. Dalam perjalanan ini, tanpa disangka, Kayla kembali dipertemukan dengan seorang lelaki dari masa lalunya. Lelaki itu dipanggil oleh Kayla dengan nama Gringgo, seorang perwira tentara yang dulu menjadi penjaga keamanan di NTT. Selama perjalanan Kayla di Kupang dan Pulau Lembata, mereka terus bertemu dan kembali menjalin kasih yang lama tertunda. Pertemuan-pertemuan penyambung rindu Kayla dan Gringgo berpadu 
dengan pengalaman perjalanan Kayla melihat sisi pariwisata yang indah, natural, penuh kearifan lokal, dan sederhana di Lembata. Ada alam pegunungan yang asri, pantai yang masih perawan, desa-desa tradisional dengan ritual adat dan keramahan masyarakatnya, tradisi berburu ikan paus yang eksotik, kain tenun, sasando, matahari tenggelam, serta bulan terbit yang romantis.

Keindahan alam serta keramahan masyarakat yang ditemui Kayla selama perjalanan wisata itu membuatnya ingin menetap di NTT dan hidup bersama dengan Gringgo. Namun, romansa Kayla dan Gringgo mendapat pertentangan dari sahabatnya Eleonora, sebab tidak ada seorangpun yang pernah benar-benar bertemu Gringgo selain Kayla. Eleonora merasa hubungan Kayla dan Gringgo terlalu misterius, ditambah lagi Kayla masih terikat status pernikahan walaupun hanya tinggal di atas kertas. Kemudian, Kayla secara misterius bertemu seorang lelaki tua yang memberi peringatan keras kepadanya agar tidak menggangu Gringgo, karena hubungan mereka sudah terlambat. Lelaki tua itu mengaku diberi mandat oleh leluhur Gringgo untuk menjaganya. Setelah pertemuan Kayla dengan lelaki tua tersebut, perlakuan Gringgo kepadanya juga berubah, dia tampak lebih hati-hati dalam bertindak. Adanya peringatan misterius, ditambah ujaran Gringgo yang menginginkan Kayla untuk tidak menetap di NTT, dan juga kuatnya pernyataan ketidaksetujuan Eleonora, sahabatnya, terhadap hubungan Kayla dengan Gringgo, akhirnya membuat Kayla kembali ke Jakarta dengan perasaan yang hancur. Akan tetapi, Kayla tetap punya hasrat kuat untuk kembali lagi ke NTT nantinya.

\section{Analisis Faktor Internal dan Eksternal}

Berdasarkan hasil observasi terhadap isi novel, wawancara dengan pembaca, serta diskusi mendalam dalam FGD mengenai topik potensi novel Cintaku di Lembata karya Sari Narulita sebagai media promosi pariwisata Lembata - NTT, maka 
didapatkan beberapa hal yang dapat dirumuskan untuk mengisi faktor-faktor internal dan eksternal berikut:

\section{a. Analisis Faktor Internal - Kekuatan}

- Isi novel menarik untuk dibaca

Untuk dapat menjadi suatu media promosi tentu saja suatu hal harus menarik untuk dilihat, atau dalam kasus novel, harus menarik untuk dibaca. Respon pembaca mengatakan bahwa alur penceritaan di dalam novel, serta penyajian ceritanya mampu membuat pembaca untuk terus membaca hingga tuntas. Bahkan bagian sinopsis yang ditampilkan di bagian belakang sampul novel mampu menggelitik rasa ingin tahu pembaca mengenai isi novel.

- Novel bertema perjalanan

Novel ini memberikan informasi jelas mengenai destinasi wisata seperti atraksi, akses, akomodasi, hingga kondisi masyarakatnya. Melihat kembali tujuan promosi adalah untuk memberikan informasi, maka novel ini sudah sarat informasi. Respon pembaca mengatakan bahwa mereka mendapatkan banyak informasi mengenai keadaan di Lembata, bagaimana cara mengaksesnya, kondisi akomodasi, kondisi alam yang ternyata beragam, hingga kondisi sosial-ekonomi masyarakatannya. Hal ini menjadikan novel ini berperan seperti panduan perjalanan yang dikemas dalam bentuk cerita.

- Keindahan destinasi dan keramahan masyarakat tradisional digambarkan dengan sangat jelas.

Pembaca merespon bahwa penggambaran dalam novel bisa membuat mereka merasakan perjalanan itu sendiri, sehingga pembaca merasa ikut dibawa ke sana. Kalangan pembaca merasakan ketertarikan secara emosional untuk mengunjungi Lembata walaupun ada penggambaran fasilitas-fasilitas yang kurang memadai dan 
masih tradisional. Penerimaan masyarakat yang tampak seperti menyambut keluarga menjadi salah satu faktor ketertarikan mereka.

- Cara penceritaan menunjukkan kecintaan penulis terhadap daerah NTT.

Beberapa pendapat pembaca mengatakan bahwa mereka dapat melihat wujud kecintaan penulis terhadap NTT dalam novel ini. Hal ini dapat dirumuskan sebagai kekuatan, karena sisi kecintaan ini dapat menjadi daya tarik emosional dan moral untuk mengunjungi Lembata dan menerima segala kekurangan serta kelebihannya.

- Mengandung unsur kritik sosial

Kritik sosial yang muncul berkaitan dengan adanya unsur ajakan bagi pemuda NTT untuk kembali dan membangun daerahnya serta kritik terhadap masih kurang meratanya pembangunan di Indonesia. Hal ini dapat menjadi suatu daya tarik moral bukan hanya bagi pemuda NTT yang merantau, tetapi juga dapat berdampak persuasif secara moral bagi pemuda Indonesia pada umumnya dengan cara menggugah kesadaran mereka untuk berpartisipasi membangun daerah-daerah timur. Salah satu caranya tentu saja dengan berkunjung dan berwisata ke bagian timur Indonesia. Bentuk-bentuk kritik sosial juga menunjukkan Lembata apa adanya, sehingga novel ini dapat menjadi media promosi yang mirip seperti ulasan wisatawan daripada murni media promosi seperti iklan.

- Tokoh perempuan yang tidak lagi muda

Banyak pendapat umum yang mengatakan bahwa berwisata ke daerah timur Indonesia, termasuk Lembata tentunya, akan menjadi suatu perjalanan yang sulit dan penuh tantangan, sehingga para traveler perempuan bisa saja merasa kawatir, seperti beberapa pendapat dari pembaca novel Cintaku di Lembata ini. Namun, dengan menggunakan tokoh utama pelaku perjalanan adalah seorang perempuan paruh 
baya, novel ini dapat menunjukkan bahwa ternyata perjalanan ke Lembata - NTT sangat memungkinkan untuk dilakukan bahkan oleh perempuan yang kondisi fisiknya bisa jadi sudah tidak optimal lagi.

- Menunjukkan destinasi yang aman

Cerita dalam perjalanan tokoh Kayla ke Lembata menceritakan pertemuanpertemuan dengan masyarakat yang ramah, baik, dan siap menolong. Diceritakan pula bahwa kondisi stabilitas keamanan di NTT sudah jauh berbeda dengan kemajuan-kemajuan perkembangan pembangunan. Terdapat bagian kilas balik yang memberikan perbandingan kondisi NTT pada masa silam dengan kondisi di tahun 2014, sesuai dengan periode tahun cerita. Digambarkan oleh tokoh Kayla bahwa NTT sudah jauh berubah, termasuk dalam kondisi stabilitas keamanan. Tentu saja situasi aman adalah hal yang penting untuk dipromosikan oleh destinasi.

- Terdapat bagian yang menceritakan tentang atraksi-atraksi unik di Lembata

Cerita perjalanan dalam novel Cintaku di Lembata ini menunjukkan beragam atraksi unik yang dapat dijumpai di Lembata. Beberapa contohnya yang dianggap menarik oleh pembaca adalah kegiatan perburuan ikan paus di Lamalera yang menggunakan peralatan tradisional, adanya pasar barter yang langka, kampung adat lama, tenun, dan kopi khas Lembata. Atraksi-atraksi ini cukup menggugah keingintahuan pembaca untuk mencari tahun lebih lanjut, dan bahkan ingin mengalami secara langsung.

- Sisi cerita yang misterius dianggap menarik

Sisi cerita antara Kayla dan Gringgo yang misterius ternyata juga menjadi daya tarik tersendiri bagi pembaca. Baik daya tarik dalam hal membuat pembaca ingin membaca cerita hingga tuntas, maupun daya tarik yang menjadikan NTT memiliki kesan-kesan misterius yang menarik untuk dieksplorasi. Kesan misterius ini juga 
berkaitan dengan masih kentalnya kearifan lokal yang dipegang teguh oleh penduduk setempat.

- Terdapat puisi tentang Lembata yang juga dianggap menarik

Isi novel ini juga menyajikan puisi yang semakin mempertegas sisi kerinduan penulis untuk kembali ke Lembata. Kerinduan untuk kembali pasti didasarkan oleh kecintaan, dan kecintaan didasari oleh sesuatu yang daya tarik kuat yang menjadikan sesuatu patut dicintai. Isi puisi ini merupakan daya tarik emosional tersendiri yang disajikan oleh novel Cintaku di Lembata.

\section{b. Analisis Faktor Internal - Kelemahan}

Faktor kelemahan novel Cintaku di Lembata dalam mempromosikan pariwisata dapat dilihat sebagai berikut:

- Faktor penulis yang saat ini sudah kurang populer mempengaruhi popularitas buku

Sari Narulita merupakan artis peran di masa mudanya, kemudian menjadi penulis fiksi dan jurnalis. Beliau juga sempat memimpin majalah-majalah waralaba dari luar negeri seperti Cosmopolitan, Her World, Bride, dan Maxim (Beritasatu, 2014). Namun, rupanya di antara penulis-penulis lainnya pada era millennial ini, Sari Narulita kurang populer. Hal ini diperkirakan sebagai salah satu sebab novel-novel karyanya kurang baik dalam hal penjualan, menurut narasumber yang bergerak di bidang kesastraan dan penerbitan. 
- Penceritaan yang sangat detail dan luas membuat fokusnya terlalu banyak kalau untuk media promosi

Beberapa narasumber pakar dalam diskusi memberikan masukkan bahwa dalam mempromosikan destinasi harus dipilih prioritasnya. Membuat fokus terhadap atraksi yang paling menarik itu perlu. Pemilihan fokus ini memungkinkan untuk pengolahan promosi menjadi lebih maksimal. Jika satu atau beberapa fokus atraksi sudah dikenal luas, maka atraksi-atraksi lainnya akan mengikuti.

- Kisah percintaan antara dua orang yang sudah di usia lewat paruh baya bisa jadi kurang menarik bagi pembaca

Kisah perjalanan perempuan yang sudah lewat paruh baya bisa jadi merupakan kekuatan, namun kisah cinta antara dua orang yang sudah tidak lagi muda bisa jadi kurang menarik untuk pembaca muda.

- Kisah cinta dalam novel terlalu klise dan kurang kuat untuk mempengaruhi secara emosional. Hanya berperan sebagai pengantar saja.

Beberapa pembaca menilai bahwa kisah cinta antara Kayla dan Gringgo terlalu klise dan kurang kuat dari segi cerita untuk bisa mempengaruhi citra Lembata secara emosional. Hal ini menyebabkan kisah romansa tersebut hanya dianggap sebagai suatu kemasan yang digunakan untuk menghantarkan cerita saja.

- Ada bagian-bagian cerita yang menunjukkan keluhan terhadap fasilitas di Lembata.

Di dalam novel terdapat bagian-bagian yang mengutarakan keluhan terhadap fasilitas akomodasi di Lembata. Ini sesungguhnya merupakan kewajaran dari segi narasi, karena tokoh utama adalah perempuan dari Jakarta yang sudah biasa termanjakan dengan fasilitas. Namun, bagi pelaku pemasaran pariwisata, sebuah promosi tidak boleh menunjukkan keluhan, semuanya harus dianggap bagus. 
- Mengandung unsur kritik sosial

Kritik sosial di dalam novel bisa menjadi kelemahan karena menunjukkan ketidaksiapan Lembata sebagai sebuah destinasi.

- Bagian yang menyoroti perburuan ikan paus oleh Lamafa yang heroik kurang disoroti

Hasil diskusi menunjukkan bahwa kisah heroik sang Lamafa adalah atraksi yang paling menarik yang harusnya lebih banyak ditonjolkan, karena atraksi ini adalah atraksi satu-satunya di dunia. Selain itu, tidak mudah untuk dapat menyaksikan atraksi perburuan ikan paus, karena tidak terjadi secara terjadwal. Hal ini menjadikan atraksi sang Lamafa ini dapat menjadi suatu daya tarik yang mahal.

- Kisah misterius juga bisa membawa kesan mistis

Selain membawa kesan misterius yang positif, ternyata kisah keberadaan Gringgo yang misterius juga ditanggapi pembaca sebagai sesuatu yang mistis. Hal ini tentu akan berpengaruh pada minat wisatawan.

\section{c. Analisi Faktor Eksternal - Peluang (O)}

Peluang-peluang yang berasal dari faktor lingkungan luar novel Cintaku di Lembata dapat dilihat sebagai berikut:

- Pembaca cenderung mengapresiasi positif penggambaran Lembata

Pembaca mengapresiasi positif terhadap isi novel dan dianggap sebagai novel yang bagus dari segi penceritaan. 
- Karena pandemi, terdapat tren wisata yang menjauhi keramaian

Pelaku industri perjalanan wisata mengatakan bahwa tren wisatawan ke depan akan juga mengarah pada tempat-tempat wisata yang menjauhi keramaian karena alasan kesehatan.

- Pandemi memberi waktu untuk menyusun strategi baru

Dengan adanya pandemi, industri pariwisata diberi waktu rehat untuk menyusun strategi baru, termasuk dalam hal pemasaran pariwisata. Dalam masamasa tunggu ini, pemerintah dan para stakeholder dapat memikirkan bentuk-bentuk promosi baru maupun arah-arah pengembangan wisata baru yang dapat menjawab kebutuhan pasar tanpa harus secara bersamaan berpacu dengan destinasi lainnya. Sebagai contoh, pengembangan wisata virtual dan wisata glamping.

- Wisatawan mencari destinasi baru yang eksotik

Tren wisatawan yang mencari tempat-tempat wisata baru yang eksotik masih tetap ada dan semakin berkembang.

- Terdapat pangsa pasar wisatawan adventurer

Menurut pelaku industri perjalanan wisata, tren pasar wisatawan adventurer semakin luas saat ini dan di masa depan. Terutama setelah masa-masa isolasi ini, maka akan ada pasar wisatawan yang ingin berpetualang.

- Pangsa pasar domestik bisa diolah karena bepergian ke luar negeri masih belum memungkinkan

Pasar domestik merupakan pasar yang dapat diolah, karena perjalanan lintas negara masih mengkawatirkan dan belum diketahui kapan bisa menjadi benar-benar aman. 
- Pangsa pasar Cina, India, dan Timur Tengah dianggap potensial untuk masa mendatang

Terdapat potensi pasar Cina, India, dan Timur Tengah. Menurut pakar pemasaran pariwisata hal ini disebabkan tiga negara ini memiliki persentase warga berpengahasilan tinggi yang cukup besar.

- Adanya dukungan pemerintah dan stake holder.

Salah satu dukungan pemerintah dapat dilihat dari adanya kampanye gerakan berwisata di Indonesia saja. Adanya kampanye untuk berwisata di Indonesia saja tentunya memberikan angin segar bagi destinasi-destinasi di Indonesia untuk bisa mentargetkan pangsa pasar dalam negeri. Dukungan lainnya adalah dengan penetapan Destinasi Super Prioritas, salah satunya ialah Labuan Bajo. Hal ini dapat menjadi kesempatan untuk Lembata ikut dipaketkan dalam paket-paket perjalanan ke daerah Labuan Bajo tersebut. Selain itu, menurut salah satu perwakilan stake holder pariwisata Lembata, saat ini destinasi ini sedang meningkatkan kualitas fasilitas, akses, dan juga kualitas SDM.

- Terdapat tren pengembangan Quality Tourism yang mengutamakan visual, behavior, dan Reflection

Salah satu narasumber dalam FGD menyinggung tentang tren pariwisata berkualitas yang salah satunya menyoroti adanya faktor reflection yang dalam hal ini berati edukasi. Maksudnya adalah, kegiatan pariwisata juga diharapkan memberikan sisi edukasi kepada para pelaku pariwisatanya, baik dari sisi host maupun sisi wisatawan. Hal ini adalah kesempatan bagi destinasi-destinasi yang mengangkat kearifan lokal untuk memberikan wawasan kepada wisatawan tentang way of life mereka yang unik. 
Potensi Novel Cintaku di Lembata Karya Sari Narulita sebagai Media Promosi Pariwisata Lembata...

- Semakin meluasnya penggunaan media sosial untuk promosi.

Saat ini penggunaan media sosial menjadi semakin luas dan mempermudah promosi pariwisata jika bisa dimanfaatkan dengan maksimal.

- Banyak contoh kasus novel yang difilmkan dan bisa mendapat penonton dgn jumlah banyak dan menjadi box office

Melihat pada banyak contoh kasus sebelumnya dimana film sangat mampu mendongkrak popularitas suatu destinasi, maka pembuatan bentuk film dari cerita novel Cintaku di Lembata sangat mendapatkan dukungan dari para peserta FGD maupun pembaca.

- Perfilman Indonesia sudah mulai kembali menggeliat

Saat ini sudah banyak sekali film Indonesia berkualitas dengan penonton yang banyak juga jumlahnya.

- Banyak sineas-sineas muda berbakat yang ingin mengangkat potensi dalam negeri.

Narasumber dari kalangan perfilman mengatakan bahwa topik-topik yang mengangkat keindahan alam dan keunikan tradisi lokal saat ini sangat menarik untuk diangkat menjadi film.

\section{d. Analisis Faktor Eksternal - Ancaman (T)}

- Minat baca masyarakat saat ini sangat kurang

Berkurangnya minat baca tentu saja mempengaruhi segi efektifitas promosi jika narasi dalam novel tidak dialihbentukkan ke media lain, seperti film. 
- Banyak sumber bacaan gratis dan persaingan dengan penulis-penulis populer yang menggunakan platform digital.

Saat ini jumlah pasar pembaca buku dalam negeri sudah tidak terlalu besar. Di dalam pasar yang kecil ini, novel-novel harus saling bersaing. Persaingan juga muncul karena banyaknya sumber bacaan gratis yang menawarkan cerita-cerita yang juga menarik, terutama dari platform digital seperti wattpad dan storial, maupun ceritacerita webtoon yang saat ini banyak digemari.

- Kondisi pandemi membuat perekonomian sedang krisis.

Kondisi finansial global yang sedang krisis tentu saja sangat mempengaruhi kondisi pariwisata. Hal ini karena kemampuan orang untuk bepergian memnjadi terbatas. Orang akan cenderung mementingkan kebutuhan-kebutuhan utama terlebih dahulu.

- Kondisi yang belum stabil membuat pangsa pasar Internasional masih sulit untuk dijadikan target pasar.

Perjalanan lintas batas negara yang masih belum memungkinkan, serta kondisi pandemi masih sulit diprediksi kapan dapat benar-benar pulih, membuat pangsa pasar internasional masih belum dapat dijadikan target pasar utama.

- Pangsa pasar domestik cenderung terbiasa dengan fasilitas yang lengkap.

Hal ini disampaikan oleh pelaku industri perjalanan wisata yang menyebutkan bahwa wisatawan domestik cenderung mencari wisata-wisata yang menawarkan kenyamanan dengan fasilitas memadai. Jika fasilitas di Lembata masih belum dibenahi, seperti yang diceritakan di novel, maka akan sulit juga menargetkan pasar domestik. 
- Jumlah wisatawan adventurer untuk domestik masih kurang.

Sulitnya mentargetkan pasar domestik, menurut pelaku industri perjalanan wisata, juga berkaitan dengan masih kurangnya jiwa adventurer di kalangan wisatawan Indonesia.

Strategi Pemanfaatan Novel Cintaku di Lembata sebagai media promosi Lembata NTT.

Berdasarkan penjabaran faktor-faktor internal dan eksternal dari novel Cintaku di Lembata, maka dapat dirumuskan beberapa faktor kunci dalam hal kekuatan, kelemahan, peluang, dan ancaman sebagai berikut:

Faktor kunci kekuatan (S) novel dari segi isi dan penulis:

1) isi novel yang informatif dan persuasif;

2) memiliki daya tarik emosional dan moral;

3) menunjukkan atraksi-atraksi di destinasi baru yang menarik dan unik;

4) realistis sehingga seperti ulasan perjalanan;

5) ada kritik sosial;

6) menunjukkan kecintaan penulis terhadap Lembata; dan

7) Tokoh perjalanan perempuan yang tidak lagi muda.

Faktor kunci kelemahan (W) novel dari segi isi dan penulis:

1) fokus cerita yang terlalu luas dan detail;

2) kisah roman yang klise;

3) terdapat bagian yang melontarkan keluhan-keluhan terhadap fasilitas di destinasi, terutama yang berhubungan dengan kamar mandi dan air; 
4) atraksi unik perburuan ikan paus kurang banyak disorot; dan

5) kisah yang misterius dapat mengarah ke kesan mistis

Faktor kunci peluang $(\mathrm{O})$ dari lingkungan eksternal novel:

1) apresiasi pembaca yang positif;

2) adanya tren-tren wisata berkualitas yang menjauhi wisata massal dan mengandung unsur reflektif;

3) adanya pangsa pasar wisatawan adventurer;

4) ada kesempatan untuk mengolah pasar domestik, kondisi pandemi justru memberikan kesempatan untuk mengekplorasi strategi baru dan bentukbentuk wisata jenis baru;

5) penggunaan media sosial yang semakin luas memudahkan promosi;

6) film yang diangkat dari novel banyak yang sukses dan dapat memberikan dampak promosi lebih besar;

7) cerita yang mengangkat kearifan lokal sedang banyak diminati sineas; dan

8) dudah ada dukungan pemerintah dan stakeholder dalam membangun fasilitas dan SDM.

Faktor kunci ancaman (T) dari lingkungan eksternal novel:

1) menurunnya minat baca pembaca dalam negeri dan persaingan dengan novelnovel gratis berbentuk digital;

2) kondisi pandemi membuat adanya krisis ekonomi;

3) pangsa pasar internasional masih belum tahu kapan bisa diolah; dan 
4) wisatawan domestik yang adventurer masih kurang dan terbiasa dengan fasilitas yang memadai.

Melihat penjabaran fokus elemen kekuatan, kelemahan, peluang dan tantangan di atas maka dapat dirumuskan beberapa strategi yang dapat diterapkan untuk memanfaatkan novel Cintaku di Lembata sebagai media promosi Lembata - NTT, diantaranya:

Strategi S-O

1. Memanfaatkan bentuk storytelling dalam novel Cintaku di Lembata dalam media promosi untuk mengoptimalkan daya tarik emosional dan moral.

2. Menerjemahkan cerita Cintaku di Lembata ke dalam beberapa bentuk media promosi termasuk media sosial dan film.

3. Mempertahankan sifat realistis cerita agar tetap memiliki persuasi yang terselubung.

4. Mengeksplorasi wisata jenis baru seperti virtual tourism yang mengangkat kisah Cintaku di Lembata.

\section{Strategi S-T}

1. Pemanfaatan kisah dalam novel tidak hanya bergantung pada bentuk teks saja.

2. Menerjemahkan aspek informatif dalam novel yang berkaitan dengan akses dan akomodasi dalam bentuk paket perjalanan yang rasional dari segi biaya.

3. Mengamplifikasi sisi kecintaan penulis pada Lembata yang ditunjukkan dalam novel untuk mempengaruhi minat wisatawan domestik untuk mengekplorasi wisata Lembata.

4. Menyoroti kehadiran tokoh perempuan yang tidak lagi muda untuk mengispirasi para traveler muda untuk menjelajahi Lembata. 
Strategi W-O

1. Mengangkat ke dalam bentuk film dengan fokus pada atraksi-atraksi yang ingin diprioritaskan, seperti misalnya atraksi perburuan ikan paus.

2. Mengemas cerita sehingga kurangnya fasilitas bukan menjadi keluhan namun bagian dari petualangan.

3. Mengarahkan kisah misterius kepada unsur kearifan lokal dan bukan kepada unsur mistis.

4. Perbaikan fasilitas dan SDM dapat diprioritaskan pada fasilitas-fasilitas yang berhubungan dengan sanitasi.

Strategi W-T

1. Membuat film-film mini, atau film serial mini yang diangkat dari novel Cintaku di Lembata.

2. Potongan-potongan cerita dapat difokuskan pada atraksi-atraksi tertentu yang sangat menarik.

3. Film-film mini ini dapat dipublikasikan dan dipromosikan melalui media sosial untuk menggugah rasa penasaran pembaca atau penonton. Usaha menggugah rasa penasaran ini juga diharapkan dapat menarik wisatawan, baik domestik maupun internasional untuk berani melakukan perjalanan yang bersifat adventure.

4. Atraksi-atraksi yang dapat dipilih adalah atraksi perburuan ikan paus, kampung lama Lamagute, makanan khas NTT, dan kopi NTT.

5. Sisi misterius cerita harus diarahkan kepada nuansa kearifan lokal agar tidak mengarah ke tanggapan mistis.

480 JUMPA Volume 7, Nomor 2, Januari 2021 


\section{Simpulan dan Saran}

Berdasarkan hasil diskusi dan respon pembaca, diketahui bahwa novel Cintaku di Lembata memang sangat potensial untuk dikembangkan menjadi media promosi pariwisata Lembata. Namun, untuk dapat memenuhi tujuan promosi pariwisata secara maksimal, dalam hal ini untuk menginformasikan dan membujuk, maka ada beberapa hal dari faktor internal dan eksternal yang harus diperhatikan, yaitu 1) unsur rasa cinta penulis kepada Lembata yang tertuang dalam bentuk novel perjalanan wisata ini sangat memungkinkan untuk diamplifikasi sehingga dampaknya menjadi luas dan mempengaruhi penonton secara emosional dan moral untuk mengunjungi Lembata, 2) hasil analisis SWOT menunjukkan bahwa diperlukan adanya integrasi pemanfaatan berbagai macam media dalam menerjemahkan novel Cintaku di Lembata ini agar dapat menjadi media promosi yang maksimal, dan 3) kisah dalam novel merupakan bahan baku yang dapat diolah menjadi berbagai macam bentuk media promosi, baik yang bersifat kognitif maupun yang bersifat afektif, hingga nantinya yang bersifat konatif dalam bentuk pembuatan paket perjalanan bertema Cintaku di Lembata.

\section{Ucapan Terima Kasih}

Penulis ingin mengucapkan terima kasih kepada para narasumber yang telah memberikan banyak pandangan dan masukan dalam forum focus group discussion mengenai potensi novel Cintaku di Lembata. Ucapan terima kasih diberikan terutama kepada Prof. Dr. I Nyoman Darma Putra, M.Litt. selaku narasumber pakar di bidang sastra pariwisata, bapak Eddy Sunyoto sebagai perwakilan ASITA selaku narasumber pakar di bidang pemasaran pariwisata, Nelsye Lumanauw, S.E., M.Par. dan bapak Robert Koni selaku narasumber perwakilan industri perjalanan pariwisata, Made Handijaya Dewantara, SST. Par., M.Par., M.Pro. selaku narasumber perwakilan akademisi dan peneliti di bidang pariwisata. 


\section{Daftar Pustaka}

Andriansyah, Tati Rajati, dan Fatia Fatimah. 2012. "Novel Dan Film Media Pemicu Pengembangan Pariwisata dalam Menanggulangi Kemiskinan". Jurnal Bisnis E Manajemen. Vol 9(1).

Beritasatu. 2014. "Pembuktian Sari Narulita dalam Damn Lebih Indah dari Cinta". Sumber URL: https://www.beritasatu.com/iman-rahmancahyadi/hiburan/204337/pembuktian-sari-narulita-dalam-damn-lebih-indahdari-cinta diakses 12 Oktober 2020.

Dinas Komunikasi dan Informasi Kabupaten Lembata. 2019. "Kabupaten Lembata", sumber URL: https://site.lembatakab.go.id/ diakses 17 Oktober 2020.

Kotler, Philip dan Gary Armstrong. 2012. Principles of Marketing. Boston: Prentice Hall.

Lukitasari, Rimalinda. 2017. "Bujukan Berwisata ke Bali: Simbol-simbol Promosi Pariwisata Film 'Eat Pray Love'”. Jurnal Master Parwisata. Vol 3(2) Hal.323-338.

Narulita, Sari. 2016. Cintaku di Lembata. Jakarta: PT. Gramedia Pustaka Utama.

Puslitjakdikbud. 2019. Indeks Aktifitas Literasi Membaca 34 Provinsi. Jakarta: Pusat Penelitian Kebijakan Pendidikan dan Kebudayaan, Badan Penelitian dan Pengembangan, Kementerian Pendidikan dan Kebudayaan

Rahmadiani, Meilina. 2014. (Skripsi). "Pengaruh Film 5cm Terhadap Minat Remaja Wisata Ke Taman Nasional Bromo Tengger Semeru (Studi Pada Siswa/siswi SMA Negeri 9 Bandar Lampung)". Universitas Lampung.

Suwantoro, Gamal. 2004. Dasar-Dasar Pariwisata. Yogyakarta: ANDI.

Wibowo, Lili Adi dan Donni Juni Priansa. 2017. Manajemen Komunikasi dan Pemasaran. Bandung: Alfabeta.

Yoeti, Oka. A. 2013. Pemasaran Pariwisata. Bandung: Angkasa. 
Potensi Novel Cintaku di Lembata Karya Sari Narulita sebagai Media Promosi Pariwisata Lembata...

\section{Profil Penulis}

Rimalinda Lukitasari menyelesaikan pendidikan strata satunya di Universitas Udayana dengan mengambil jurusan Sastra Inggris. Pendidikan strata dua diselesaikan di program studi magister Kajian Pariwisata Universitas Udayana. Fokus bidang penelitian yang menjadi minat penulis adalah di bidang promosi pariwisata khususnya yang berhubungan dengan karya-karya naratif. Saat ini penulis adalah seorang dosen di Politeknik Internasional Bali. Selain di dunia pendidikan, penulis juga aktif di industri pariwisata sebagai seorang event planner profesional, mengelola homestay, dan menjadi seorang freelance copywriter untuk usaha-usaha di bidang pariwisata.

Elsita Lisnawati Guntar menyelesaikan strata satu di Universitas Udayana Program Studi Sastra Indonesia. Strata duanya ditempuh di Universitas Negeri Semarang dalam Program Studi Magister Pendidikan Bahasa Indonesia. Saat ini penulis adalah dosen di Politeknik Internasional Bali dan di STIE BIIMT Sahid Bali. Penulis memiliki kecintaan di bidang sastra dan bahasa Indonesia. Minat dan kecintaan akan sastra dan bahasa Indonesia telah membuat penulis menekuni penelitian di bidang sastra dan bahasa Indonesia, khususnya penelitian yang berkaitan novel, puisi, cerpen, dan sastra lisan.

Ni Ketut Veri Kusumaningrum menyelesaikan starta satu di Universitas Dwijendra Denpasar dan starta dua di Universitas Pendidikan Ganesha, keduanya pada jurusan Bahasa dan Sastra Indonesia. Saat ini penulis merupakan dosen MKDU di Politeknik Internasional Bali dan Universitas Teknologi Indonesia. Fokus bidang penelitian yang ditekuni penulis adalah di bidang sastra dan humaniora. 